\title{
The Effect of Stocking Density on the Performance of the Seaweed Ulva reticulata as a Biofilter in Earthen Pond Channels, Zanzibar, Tanzania
}

\author{
Flower E. Msuya \\ Institute of Marine Sciences, University of Dar es Salaam, P.O. Box 668, Zanzibar, Tanzania
}

\begin{abstract}
Key words: Stocking density, seaweed biofilter cages, integrated system, Ulva reticulata,
\end{abstract} Zanzibar

\begin{abstract}
The seaweed biofilter Ulva reticulata was grown at two stocking densities (1 and 3 $\mathrm{kg} \mathrm{m}^{-2}$ ) in a low cost integrated system in Zanzibar, Tanzania. The seaweed was stocked in $2 \mathrm{~m}^{2}$ cages made of 1 inch netting material placed at the outflow of fish ponds. Control seaweed was grown at the fish pond inflow channel.

At a stocking density of $3 \mathrm{~kg} \mathrm{~m}^{-2}$, the weight of the seaweed increased by $700 \mathrm{~g}$ (fw) during the first week and then an increase of less than $200 \mathrm{~g}$ in the fifth week. Total weight increased from $4,500 \mathrm{~g}$ at stocking to $6,630 \mathrm{~g}$ during the fifth week. Growth rate was $1.3 \% \mathrm{~d}^{-1}$. The seaweed also removed $0.4 \mathrm{~g} \mathrm{~N} \mathrm{~m}^{-2} \mathrm{~d}^{-1}$ of nitrogen from nutrient-rich fishpond effluent water. At the lower stocking density, of $1 \mathrm{~kg} \mathrm{~m}^{-2}$, biomass increased by $500 \mathrm{~g}$ during the first week increasing to 700 $\mathrm{g}$ during the fifth week. Total weight increased from $6,000 \mathrm{~g}$ at stocking to $30,000 \mathrm{~g}$ during the fifth week. Growth rate averaged 3.9\% per day. The seaweed also removed TAN of $6 \mathrm{~g} \mathrm{~N} \mathrm{~m}^{-2} \mathrm{~d}^{-1}$. The growth rate, biomass yield and nutrient uptake were significantly (ANOVA, $\mathrm{P}<0.01$ ) higher than those of the controls. The seaweed significantly raised $\mathrm{pH}$ and oxygen levels of the fish pond effluent water at both stocking densities. Therefore, both stocking densities lead to efficient performance of the seaweed biofilter Ulva reticulata, but $1 \mathrm{~kg} \mathrm{~m}^{-2}$ is better than $3 \mathrm{~kg} \mathrm{~m}^{-2}$ in this system. Higher densities are, however, known to be good in other integrated systems, calling for more work on this integrated system.
\end{abstract}

\section{INTRODUCTION}

Stocking density is one of the major factors that determine the growth and performance of seaweed biofilters. Some studies have reported on varying stocking densities in intensive and semi-intensive aerated systems, depending on the aim of the study. Vandermeulen and Gordin (1990) found that growth rate of Ulva lactuca was reduced only at a stocking density as high as $4 \mathrm{~kg} \mathrm{~m}^{-2}$. The authors also obtained three times more nitrogen content (measured as protein content) in plants stocked at $4 \mathrm{~kg} \mathrm{~m}^{-2}$ compared to those stocked at $0.5 \mathrm{~kg} \mathrm{~m}^{-2}$ and Lapointe and Tenore (1981) and DeBusk et al.
(1986) obtained similar results. Neori et al. (1991) reported that stocking density of Ulva lactuca could be increased to between $4-6 \mathrm{~kg} \mathrm{~m}^{-2}$ under sufficient nutrient concentrations to increase nitrogen content, although the biomass yield would be reduced. Lapointe and Tenore (1981) found that the specific growth rate of Ulva fasciata decreased by $94 \%$ as its density increased 18 times. Nagler et al. (2003) observed that the optimal stocking density of Gracilaria parvispora was $2 \mathrm{~kg} \mathrm{~m}^{-2}$, based on growth rates, and that the growth rate decreased only at $4 \mathrm{~kg} \mathrm{~m}^{-2}$ density, but biomass yield increased up to the highest density of $8 \mathrm{~kg} \mathrm{~m}^{-2}$. These studies depict some of the work done on stocking density 
of seaweeds, conducted using aerated systems in mostly intensive culture systems. Whereas aeration is not practical in areas where electricity is lacking, like most African countries, studies on stocking density in non - aerated systems are scarce. In Africa, mariculture is only at its initial stages of becoming commercial with limited initiatives in isolated areas of the continent. Farming of seaweed in integrated systems is therefore still at experimental stages. Integrating seaweed with the emerging mariculture development is of high potential in providing two products in the same system and also minimising the effect of mariculture to the environment. The seaweed Ulva reticulata has been used as an ingredient in fish feed to culture rabbitfish and milkfish in a fish-seaweed integrated system in Makoba, Zanzibar, Tanzania. The seaweed is a product of the integrated system and it is thus re-circulated within the integrated system as a fish feed ingredient. Culturing the seaweed using fishpond outflow water increases the protein content of the seaweed making it an ingredient of higher quality while cleaning (filtering) the nutrient-rich fishpond outflow (effluent) water. Although Eucheuma denticulatum and Kappaphycus alvarezii are commercially farmed in the country, trials using these seaweeds as biofilters were not successful as the seaweeds could not grow in the nutrient-rich outflow waters of the Makoba fish ponds (see Msuya and Neori 2002). The authors also tested Gracilaria crassa and found it to be a good biofilter in terms of growth and biofiltration ability. The current study examined the growth of the seaweed Ulva reticulata at two stocking densities $\left(1\right.$ and $\left.3 \mathrm{~kg} \mathrm{~m}^{-2}\right)$ in a non-aerated system in Zanzibar, Tanzania.

\section{MATERIALS AND METHODS}

The seaweed Ulva reticulata was collected from wild stocks at Chwaka Bay on the East Coast of Zanzibar at low tide. The seaweed was then transported to the study site, Makoba Bay, on the North West Coast of Zanzibar. Cages that were 2 $\mathrm{m}^{2}$ were constructed using netting material of 1 inch mesh size. The cages $(1 \times 2 \mathrm{~m})$ were constructed

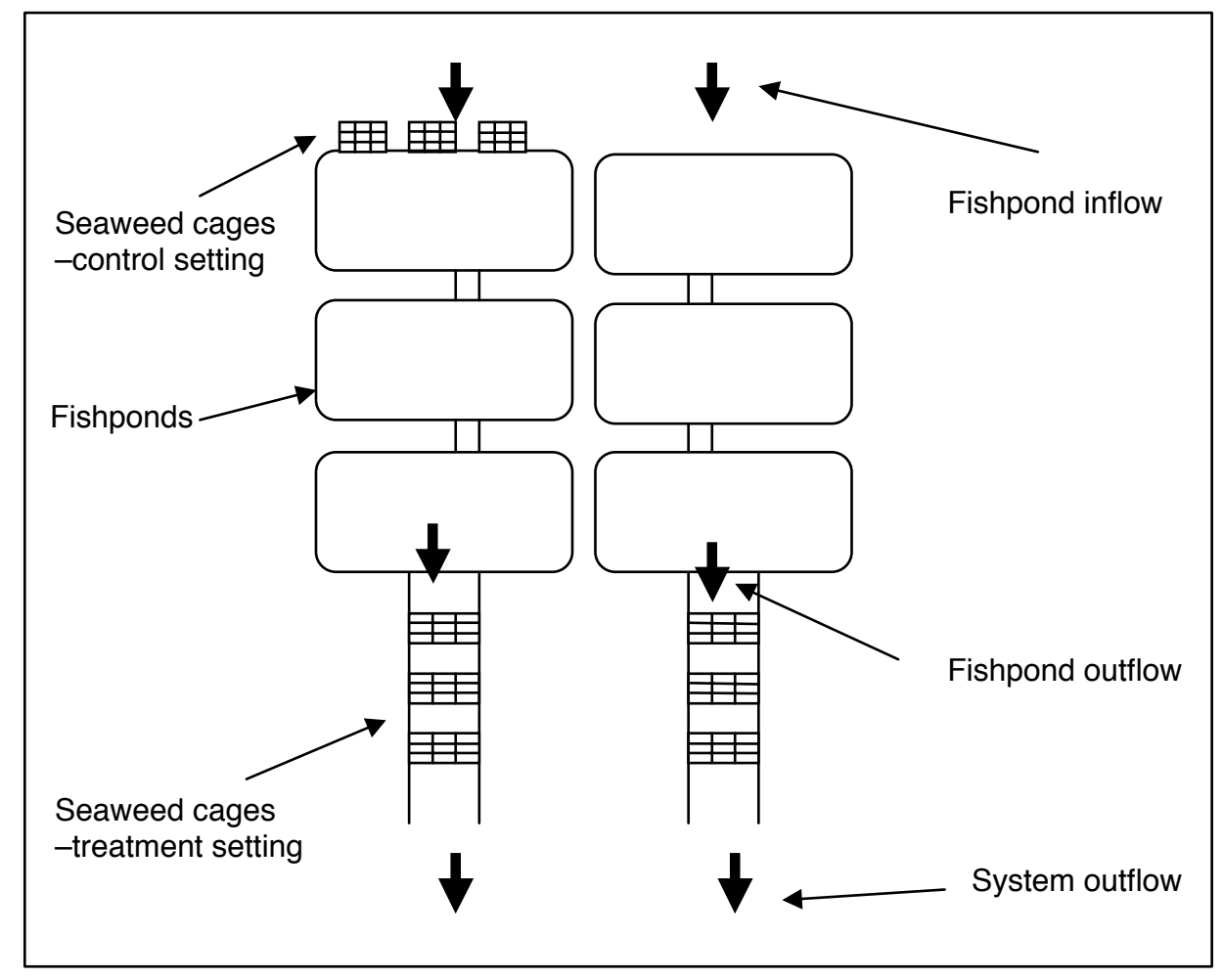

Fig. 1. The fish-seaweed integrated system used in the study 
by stretching $1 \times 2 \mathrm{~m}$ pieces of the netting material while attaching the sides with wooden pegs. The seaweed was cultivated in these cages in a threestage setting where the cages were placed in series, with three cages for each setting (see Fig. 1). Two such settings were placed at the fishpond outflow channels as treatments and two were placed at the fishpond inflow channel as controls. The channels were $20 \mathrm{~cm}$ deep and $1 \mathrm{~m}$ wide.

Two stocking densities were tested, 1 and 3 $\mathrm{kg}$ wet weight $\mathrm{m}^{-2}$. Such stocking densities have been used by other researchers, either at Makoba (Msuya and Neori 2002), or in standard aerated systems (see Vandermeulen and Gordin 1990). At a stocking density of $1 \mathrm{~kg} \mathrm{~m}^{-2}, 2 \mathrm{~kg}$ of the seaweed were placed in the cages and in the $3 \mathrm{~kg} \mathrm{~m}^{-2}, 6 \mathrm{~kg}$ were placed in the cages. Water from two semiintensive fishpond series was passed through the seaweed in the treatment whereas control seaweed received seawater with no additional nutrients from a reservoir pond. Water flowed through the seaweed by gravity at a flow rate of $3.4 \mathrm{~m}^{3} \mathrm{~h}^{-1}$ (resulting in 2,000 exchanges per day). The seaweed cages were cleaned twice a week by shaking the cages and mixing the seaweed manually to remove sediment and debris that settles on the seaweed. This study was done from October to December, 2004.

\section{Sampling and laboratory analyses}

\section{Seaweed growth rate and biomass yield}

The seaweed was harvested once a week and placed in separate containers and then squeezed and shaken to remove excess water. To obtain fresh drained weight, the seaweed from each setting was weighed on a mechanical scale. Specified amounts for the two stocking densities ( $2 \mathrm{~kg}$ and $6 \mathrm{~kg}$ for the two densities respectively) were returned to the cages for continuation of the study. Specific growth rate (SGR, \%), was calculated as:

$\mathrm{SGR}=100 \mathrm{X}\left[\ln \left(\mathrm{w}_{\mathrm{t}} / \mathrm{w}_{0}\right)\right] / \mathrm{t}$ according to Nelson $e t$ al. (2001), where $\mathrm{w}_{\mathrm{o}}$ is the initial biomass and $\mathrm{w}_{\mathrm{t}}$ is the biomass at $\mathrm{t}$ culture days.

\section{Water quality}

Water samples in triplicate were collected at the inflows and outflows of the seaweed cages once a week. The water was then kept in an icebox filled with ice cubes and transported to the laboratory.
In the laboratory, the samples were filtered through GF/C Whatman filter papers $(0.45 \mu \mathrm{m})$. Total ammonia nitrogen (TAN-NH $3+\mathrm{NH}_{4}$ ) was determined through colorimetry by formation of indofenol blue (see Parsons et al. 1984). Nutrient uptake was calculated from the difference in nutrient concentrations between the inflow and the outflow according to Cohen and Neori (1991), i.e. uptake rate $=[\mathrm{Ci}-\mathrm{Co}] / \mathrm{A}$ and uptake efficiency $=100-[\mathrm{Co} /$ $\mathrm{Ci}]^{*} 100$, where $\mathrm{Ci}$ and $\mathrm{Co}$ are the nutrient loads of the inflow and outflow waters in grams per day and A is the area of the pond. For the stocking density of $3 \mathrm{~kg} \mathrm{~m}^{-2}$, water column TAN concentrations showed high variability probably because of organic matter breakdown processes in the sediment. Therefore, nutrient uptake rates were calculated by using biomass yield and protein content. Usually, nutrient uptake rates calculated from biomass yield and protein content are similar to those from the water column analyses although a slight difference might result from the less reproducible nature of Kjeldahl protein analyses compared to the spectrophotometer nutrient analyses (Neori et al. 2003).

Oxygen concentration $\left(\mathrm{mg} \mathrm{l}^{-1}\right)$ and temperature $\left({ }^{\circ} \mathrm{C}\right)$ of the water were measured on each sampling day using an oxygen meter (OxyGuard Handy Mk III, Denmark) and pH by using a pH meter (HANNA Instruments, Canada, Model no. HI 8424). Salinity was measured by using a refractometer (Sper Scientific Ltd. USA, Model no. 300011). Water velocity was measured by using pieces of leaves and a stopwatch to measure the time taken to cover a defined distance and dividing the distance by the time elapsed.

\section{RESULTS AND DISCUSSION}

\section{Seaweed growth}

Total ammonia nitrogen (TAN) concentration ranged from 7 to $9 \mu \mathrm{M}$ in the fishpond outflow channels and $4 \mu \mathrm{M}$ in the fishpond inflow (control) channel. Cultivating seaweeds in facilities such as cages generally slows down water movement leading to deposition of solid particles at the bottom of the cages. However, no noticeable accumulation was observed in the current study probably due to the slope and shallowness of the channels. 
At the $3 \mathrm{~kg} \mathrm{~m}^{-2}$ stocking density, contamination from the seaweed Chaetomorpha crassa was observed. This probably resulted from very small pieces of the seaweed remaining after cleaning the $U$. reticulata or from still-attached fouling. The difference between initial stocked weight and final weight (cumulative weight change) of the treatment (fishpond outflow) increased by $700 \mathrm{~g}$ week $^{-1}$ during the first week, decreasing to $500 \mathrm{~g}_{\text {week }}{ }^{-1}$ during the third week and then to less than $200 \mathrm{~g}$ week $^{-1}$ in the fifth week. Total biomass increased from 4,500 $\mathrm{g}$ at stocking to 6,630 g during the fifth week (Fig. 2). The average growth rate was $1.3 \% \mathrm{~d}^{-1}$ (Table 1$)$. In the control (fishpond inflow) the weight change was on average about $300 \mathrm{~g}$ week $^{-1}$ during the first week and decreased to nil during the fifth week. Total biomass increased from $4.500 \mathrm{~g}$ at stocking to 5,000 $\mathrm{g}$ in the fourth week and then decreased to $4900 \mathrm{~g}$ during the fifth week (Fig. 2). The seaweed grew at an average rate of $0.5 \% \mathrm{~d}^{-1}$ (Table 1$)$, significantly lower (ANOVA, $\mathrm{P}<0.01$ ) than that of seaweeds grown in the treatment using inflow water.

At the stocking density of $1 \mathrm{~kg} \mathrm{~m}^{-2}$, no contamination was observed, and the weight of the seaweed increased in average by $500 \mathrm{~g}^{\text {week }}{ }^{-1}$ during the first week and by $700 \mathrm{~g}$ week $^{-1}$ during $^{-1}$ the fifth week of the treatment. Total biomass (cumulative weight) increased from an average of $6,000 \mathrm{~g}$ at initial stocking to almost $30,000 \mathrm{~g}$ during the fifth week (Fig. 3). Average growth rate was $3.9 \% \mathrm{~d}^{-1}$ (Table 1 ). In the control, weight increase per week was $71 \mathrm{~g}^{\text {week }}{ }^{-1}$ during the first week increasing to only $87 \mathrm{~g}^{\text {week }}{ }^{-1}$ during the fifth week. The total harvest increased from 6,000 at stocking to about $10,000 \mathrm{~g}$ during the fifth week (Fig. 3). The average growth rate was significantly $(\mathrm{P}<0.001)$ lower than that of seaweeds grown at the treatment $\left(2.4 \% \mathrm{~d}^{-1}\right.$, Table 1$)$.

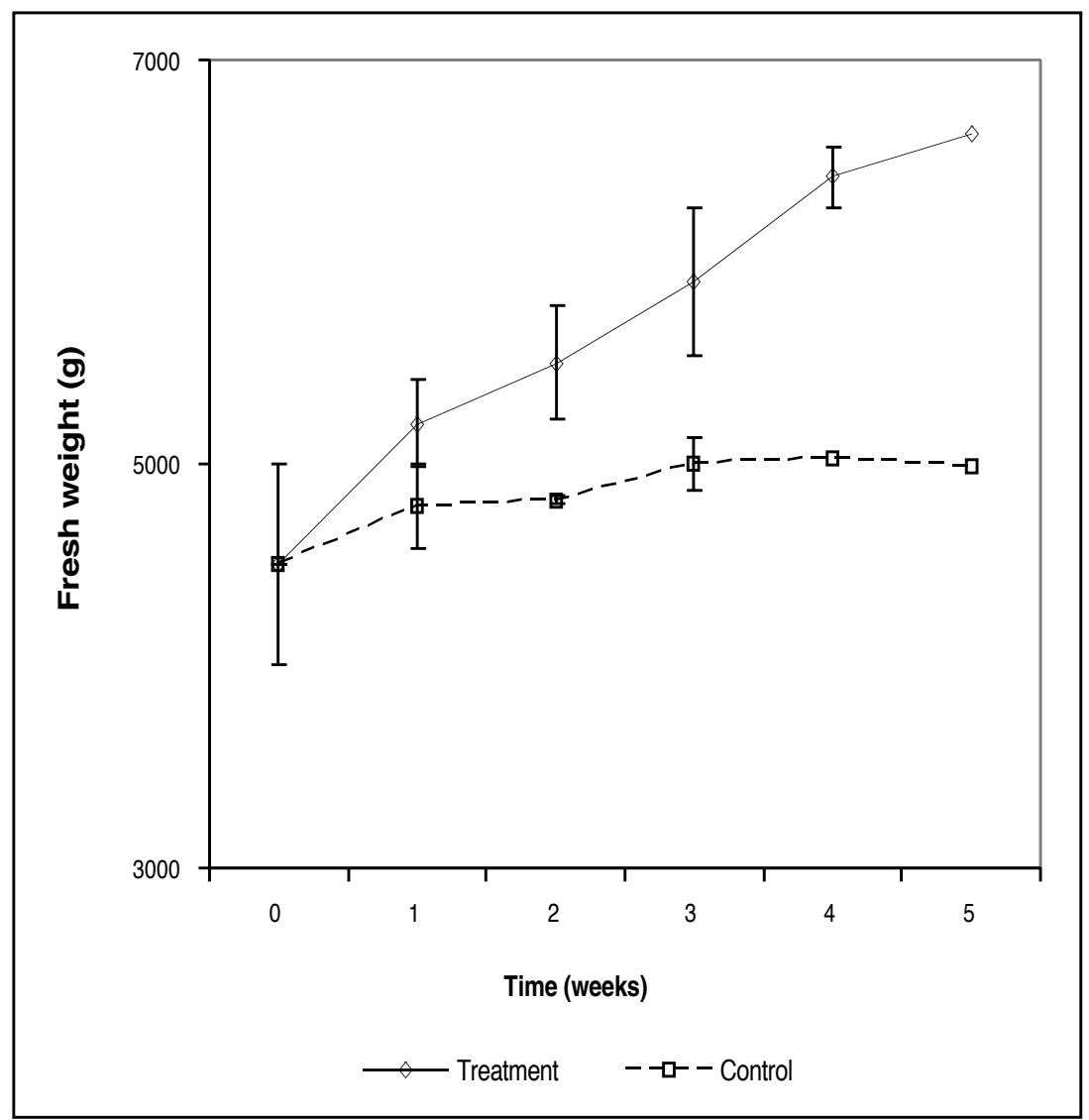

Fig. 2. Cumulative weight (g士stdev) of the seaweed Ulva reticulata grown at a stocking density of $3 \mathrm{~kg} \mathrm{~m}^{-2}, \mathrm{Makoba}$ Zanzibar. Each point is an average of six readings 
Table 1. Growth rates (SGR, \% day ${ }^{-1}$ ) and TAN uptake rates $\left(\mathrm{g} \mathrm{N} \mathrm{m}^{-2} \mathbf{d}^{-1}\right)$ (values \pm std), of the seaweed biofilter Ulva reticulata at Makoba Zanzibar

\begin{tabular}{|c|c|c|c|c|}
\hline \multirow[t]{2}{*}{$\begin{array}{l}\text { Stocking density } \\
\left(\mathrm{kg} \mathrm{m}^{-2}\right)\end{array}$} & \multicolumn{2}{|c|}{3} & \multicolumn{2}{|c|}{1} \\
\hline & Treatment & Control & Treatment & t Control \\
\hline $\begin{array}{l}S G R \\
\left(\% \text { day }^{-1}\right)\end{array}$ & $1.3 \pm 0.3$ & $0.5 \pm 0.2$ & $3.9 \pm 0.5$ & $2.4 \pm 0.6$ \\
\hline $\begin{array}{l}\text { TAN uptake } \\
\left(\mathrm{g} \mathrm{N} \mathrm{m}^{-2} \mathbf{d}^{-1}\right)\end{array}$ & 0.43 & 0.10 & $6.49 \pm 3.2$ & $1.91 \pm 1.2$ \\
\hline
\end{tabular}

An analysis of the growth in the three individual cages in the three-stage setting showed no significant difference $(\mathrm{P}>0.05)$ in growth rate between cages one, two and three. This result was found in both high and low stocking densities and in the control. Correlation analysis showed a positive relationship between growth rate/biomass yield and both nutrients and temperature, showing these factors were involved in the performance of the biofilter. The correlation was, however, not strong $(r \leq 0.307)$, suggesting that other factors, including irradiance and water motion, contributed to the growth of the biofilter.

The results of higher growth rate of seaweeds grown in the outflow (effluent) treatment, compared to those grown in the control show the advantage of culturing seaweeds at the outflows of fishponds. Fishpond outflow water with higher nutrient levels increased the growth rate of the seaweed through the provision of higher nitrogen levels. Ulva reticulata, like other species of the genus, is able to use nitrogen when available and quickly convert it into growth (Ramus and Venable 1987). The ability of the seaweed to utilise the nitrogen from the fishponds was evident at both stocking

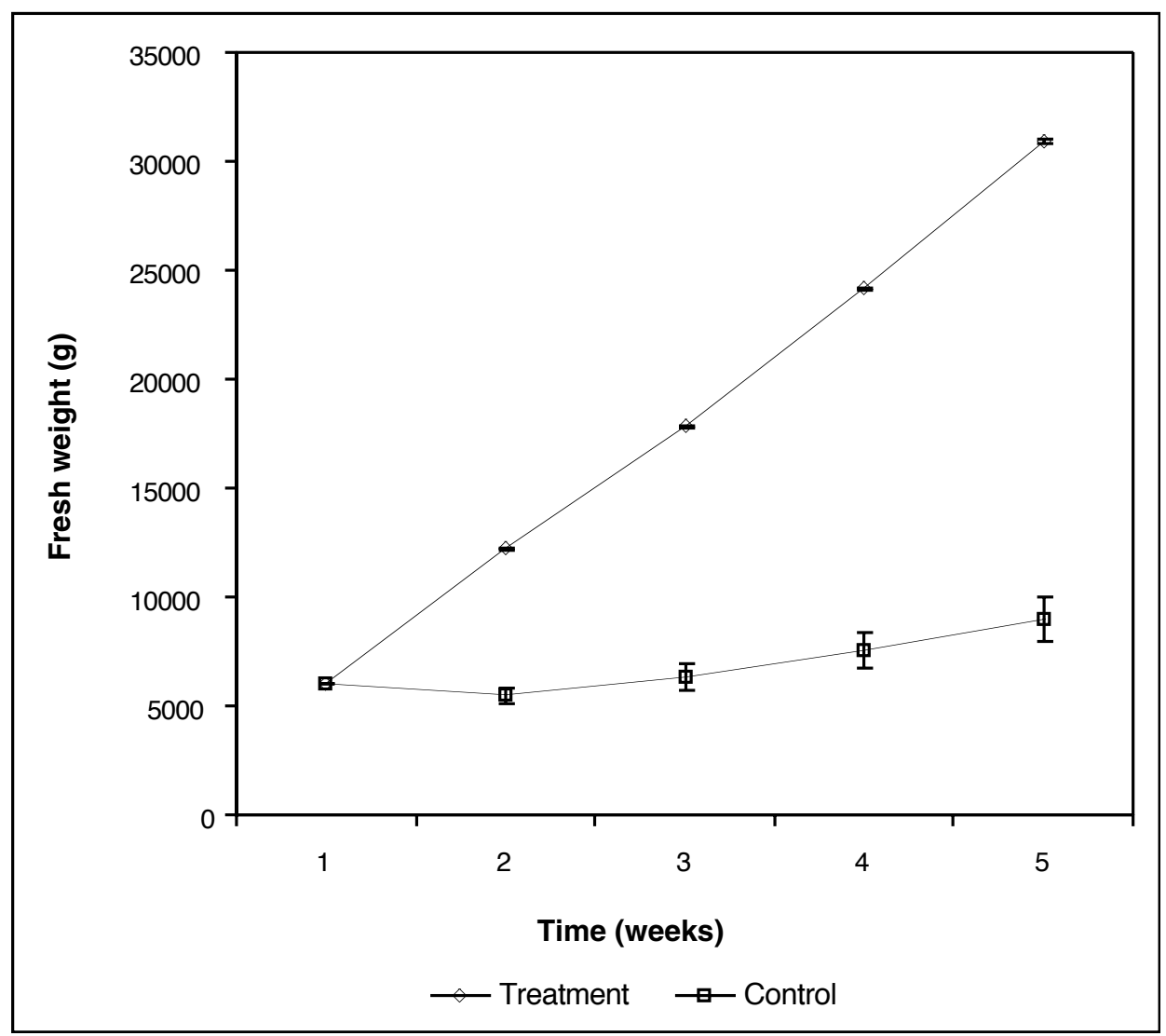

Fig. 3. Cumulative weight ( $\mathrm{g} \pm$ stdev) of the seaweed Ulva reticulata grown at a stocking density of $1 \mathrm{~kg} \mathrm{~m}^{-2}$, Makoba, Zanzibar. Each point is an average of six readings 
densities, as shown by higher growth rates of the seaweed at the treatments than the controls. A number of other studies have reported on higher growth rates of seaweeds cultured using fishpond and fish tank outflow waters, including Subandar et al. (1993), Buschmann et al. (1994) and Neori et al. (1996). The growth rate obtained at the $1 \mathrm{~kg}$ $\mathrm{m}^{-2}$ stocking density was higher than that at the 3 $\mathrm{kg} \mathrm{m}^{-2}$ indicating that for growth rate, even in this low-energy integrated system, the $1 \mathrm{~kg} \mathrm{~m}^{-2}$ stocking density is better than $3 \mathrm{~kg} \mathrm{~m}^{-2}$. Vandermeulen and Gordin (1990) reported on culturing Ulva lactuca at different stocking densities under an aerated system, and showed that the stocking densities of 1 to 1.5 give higher growth rates. However, the authors also reported that higher stocking densities of up to $4 \mathrm{~kg} \mathrm{~m}^{-2}$ did not reduce the growth rate of Ulva lactuca under the standard aerated systems. Neori et al. (1991) reported that stocking density of Ulva lactuca could be increased to between 4 and $6 \mathrm{~kg} \mathrm{~m}^{-2}$ under sufficient nutrient concentrations, to increase $\mathrm{N}$ content in the plants, but the biomass yield may be reduced. Bidwell et al. (1985) described plant densities of 5 to $6 \mathrm{~kg} \mathrm{~m}^{-2}$ as moderate densities, and explained that in such densities the plants absorb essentially all of the incident radiation. The lack of correlation between biomass/growth rate and nutrients/environmental parameters was also found in other studies, such as Glenn and Doty (1990) and Glenn et al. (1999). The lack of significant differences in growth rates between the cages in the three-stage setting may indicate similar nutrient concentrations and other growth parameters in the respective cages. Although TAN concentrations measured here were lower than those used in other studies, growth rates were comparable (e.g. 100 $\mu \mathrm{M}$ used in Israel by Neori et al. 2003). Stocking densities of seaweeds best suited for integrated mariculture systems may vary depending on the type of culture system and environmental factors.

The epiphytic Chaetomorpha crassa on Ulva reticulata at the $3 \mathrm{~kg} \mathrm{~m}^{-2}$ stocking density may have reduced the growth rate through direct competition and reduction in water velocity (as suggested by Friedlander 1992). Epiphytic red, green, and brown seaweeds are known to cause severe damage to seaweeds (Gonzalez et al. 1993). The lack of epiphytes at the $1 \mathrm{~kg} \mathrm{~m}^{-2}$ stocking density may reflect the general idea that changing culture conditions, in this case the stocking density, may reduce the problem of epiphytes; probably the lower stocking density was more favourable to the cultured seaweed than the epiphytes as was explained by Neish et al. (1977) and Bidwell et al. (1985). More work is, however, needed in this kind of integrated system to confirm the obtained results.

\section{Water quality}

\section{Salinity}

The salinity of the water varied from a minimum of $25 \mathrm{ppt}$ to a maximum of $44 \mathrm{ppt}$. The lowest salinities were recorded during rainy seasons and the highest during neap tides during which no refilling of the reservoir was achieved hence the water was not changed in the fishponds. However, the salinity was favourable for Ulva as the seaweed is known to tolerate much higher salinity ranges (Msuya and Neori 2002). Ulva lactuca, for example, is cultured in Israel under constant salinities of $40 \mathrm{ppt}$.

\section{Temperature}

The temperature of the water ranged from $25-30$ ${ }^{0} \mathrm{C}$ at both the treatment (inflow to the seaweed cages and outflow from the seaweed cages) and control (inflow to the fishpond) of the two stocking densities. There were no significant differences between the two stocking densities and the threestage cage settings $(\mathrm{P}>0.05)$. The daily temperature range did not exceed $3{ }^{\circ} \mathrm{C}$ at any day showing stable temperatures, a condition recommended for mariculture in several other studies, including that of Vandermeulen and Gordin (1990).

\section{pH}

The $\mathrm{pH}$ ranged from $7.1-8.1$ at the outflow of the fishponds and $8.1-8.9$ at the outflow of the last seaweed cage for both stocking densities and all three cages. This gives a significant $(\mathrm{P}<0.05)$ increase in $\mathrm{pH}$ of about one $\mathrm{pH}$ unit between the fishponds and the outflow of seaweed biofilter, showing the ability of the seaweed to raise the $\mathrm{pH}$ through photosynthesis. Other studies have shown the ability of the seaweed biofilter in raising the $\mathrm{pH}$ of the water including Neori et al. (1996). The $\mathrm{pH}$ range obtained here is within acceptable range for fish and seaweed farming in integrated systems 
$(6-9)$ as described by Krom et al. (1985) and Wajisbrot et al. (1991).

\section{Dissolved oxygen concentration}

Dissolved oxygen (DO) concentration of the water was significantly $(\mathrm{P}<0.001)$ increased by more than two fold from an average of $5.4 \pm 1 \mathrm{mg} \mathrm{l}^{-1}$ at the fishpond outflows to $13 \pm 2 \mathrm{mg} \mathrm{l}^{-1}$ at the outflow of the last seaweed cage for both stocking densities. Minimum DO concentrations measured were 3.1 and $9.0 \mathrm{mg} \mathrm{l}^{-1}$ for fishpond and seaweed outflows whereas the maximum concentrations were 7.8 and $17.4 \mathrm{mg} \mathrm{l}^{-1}$ respectively. The minimum DO value of $3.1 \mathrm{mg} \mathrm{l}^{-1}$ was obtained following heavy rainfall on one particular day. DO concentrations of the effluent water after passing through the seaweed biofilters were significantly raised, showing one of the qualities of the seaweed biofilters of raising the low oxygen levels of fishpond effluent water. The DO values are above safe ranges of fish growth (5 - 9, Wajisbrot et al. 1991, Qian et al. 1996) if water is to be re-circulated. The minimum acceptable oxygen concentrations for aquatic life is $3 \mathrm{mg} / \mathrm{l}$ (Mmochi et al., 2003). However, the outflow water of the system at Makoba, i.e. after the last seaweed cage, passes through unused ponds and that act as settling ponds/devices. It is, therefore, recommended to have settling ponds at the outflow of the system in case the outflow water is supersaturated and needs to be re-circulated to fishponds (see fig. 1).

\section{Nutrient uptake}

As mentioned above, for the stocking density of $3 \mathrm{~kg} \mathrm{~m}^{-2}$, nutrient uptake rates were calculated by using biomass yield and protein content. The higher stocking density may have caused the cages holding the seaweed to touch the sediment surface and re-suspend sediments that in turn may have mixed with the water column thus affecting nutrient levels. The uptake per unit area (areal uptake rate) was $0.4 \mathrm{~g} \mathrm{~N} \mathrm{~m}^{-2} \mathrm{~d}^{-1}$ in the outflow cages significantly higher $(\mathrm{P}<0.05)$ than a rate of $0.1 \mathrm{~g} \mathrm{~N} \mathrm{~m}^{-2} \mathrm{~d}^{-1}$ in the control cages (Table 1). At the stocking density of $1 \mathrm{~kg} \mathrm{~m}^{-2}$, TAN concentration from the fishpond effluents was reduced significantly after passing through the seaweed biofilter from an average of 9 to $4 \mu \mathrm{M}$. The areal uptake rate calculated from water column TAN was significantly higher $(\mathrm{P}<0.001)$ at the treatment $\left(6 \mathrm{~g} \mathrm{~N} \mathrm{~m}^{-2} \mathrm{~d}^{-1}\right)$, than at the control (1.9 $\mathrm{g} \mathrm{N} \mathrm{m}^{-2} \mathrm{~d}^{-1}$, Table 1).

The removal rates obtained here are similar to those of Neori et al. (2003) who obtained TAN areal removal rates of $0.5-0.9 \mathrm{~g} \mathrm{~N} \mathrm{~m}^{-2} \mathrm{~d}^{-1}$ in Ulva lactuca. The results are also similar to those of Cohen and Neori (1991) and Shpigel et al. (1993) who obtained TAN removal rates of up to $5.6 \mathrm{~g} \mathrm{~m}^{-2} \mathrm{~d}^{-1}$ using the same seaweed. All these authors used higher nutrient concentrations with aeration. Aeration, usually applied at the bottom of culture facilities, creates water bubbles that agitate the seaweed by moving it vertically thus optimising light exposure, removing excess oxygen, and increasing nutrient diffusion. This makes the experimental conditions in these studies much more controlled and optimal for the performance of the seaweed biofilter. The authors also used a stocking density of $1 \mathrm{~kg} \mathrm{~m}^{-2}$. The results of the current study show that even under this low-energy system, the nutrient concentration from fishpond effluent water was reduced by $55 \%$ after passing through the seaweed biofilter. For this system, where low mixing of the water may affect nutrient uptake by the seaweed biofilter, the removal rates obtained in both stocking densities are significant. In addition, the removal rates obtained here that were similar to aerated systems were obtained at much reduced costs of construction and water supply.

\section{CONCLUSION}

Stocking densities of 1 and $3 \mathrm{~kg} \mathrm{~m}^{-2}$ are both good densities in a low tech-integrated gravity generated water flow system as they result in significant growth and nutrient removal rates. A stocking density of $1 \mathrm{~kg} \mathrm{~m}^{-2}$ is better than a $3 \mathrm{~kg}$ $\mathrm{m}^{-2}$ density in this system for high growth rate and nutrient uptake by Ulva reticulata. However, higher densities have been used in other systems to show high performance and thus more work is needed to ascertain the current short-term experiments.

\section{REFERENCES}

Bidwell, R.G. S., McLachlan, J. \& Lloyd, N.D.H. (1985). Tank cultivation of Irish moss Chondrus crispus Stackh. Bot. Mar. 28: 87-97.

Buschmann, A.H., Mora, O., Gomes, P., Bottger, M., Buitano, S., Retamales, C., Vergara, P. \& Gutierrez, 
A. (1994). Gracilaria outdoor tank cultivation in Chile: use of land-based salmon culture effluents. Aquacult. Eng., 13: 283-300.

Cohen, I. \& Neori, A. (1991). Ulva lactuca biofilters for marine fishpond effluents. I. Ammonia uptake kinetics and nitrogen content. Bot. Mar., 34: 475-482.

DeBusk, T.A., Blakeslee, M. \& Ryther, J.H. (1986). Studies on the outdoor cultivation of Ulva lactuca L. Bot. Mar., 29: 381-386.

Friedlander, M. (1992). Gracilaria conferta and its epiphytes: the effect of culture conditions on growth. Bot. Mar. 35: 423-428.

Glenn, E.P. \& Doty, M.S. (1990). Growth of the seaweeds Kappaphycus alvarezii, K. striatum and Eucheuma denticulatum as affected by environment in Hawaii. Aquaculture, 84: 245255.

Glenn, E.P., Moore, D., Himler, A., Walsh, T. \& Nelson, S. (1999). Correlation between Gracilaria parvispora (Rhodophyta) biomass production and water quality factors on a tropical reef in Hawaii. Aquaculture, 178: 323-331.

Gonzalez, M.A., Barrales, H.L., Candia, A. \& Cid, L. (1993). Spatial and temporal distribution of dominant epiphytes on Gracilaria from a natural subtidal bed in central-southern Chile. Aquaculture, 116: 135-148.

Krom, M.D., Porter, C. \& Gordin, H. (1985). Causes of fish mortalities in semi-intensively operated seawater ponds in Eilat, Israel. Aquaculture, 49: 159-177.

Lapointe, B.E. \& Tenore, K.R. (1981). Experimental outdoor studies with Ulva fasciata Delile. I. Interaction of light and nitrogen on nutrient uptake, growth and biochemical composition. J. Exp. Mar. Biol. Ecol., 53: 135-152.

Mmochi, A. J., Dubi, A. M. Mamboya, F. \& Mwandya, A. Water quality variations in Makoba integrated mariculture pond system. Western Indian Ocean J. of Mar. Sci. Vol. 1(1) pp 53-63 (2002).

Msuya, F.E. \& Neori, A. (2002). Ulva reticulata and Gracilaria crassa: macroalgae that can biofilter effluent from tidal fishponds in Tanzania. Western Indian Ocean J. Mar. Sci., 1: 117-126.

Nagler, P., Glenn, E.P., Nelson, S.G. \& Napolean, S. (2003). Effects of fertilisation treatment and stocking density on the growth and production of the economic seaweed Gracilaria parvispora (Rhodophyta) in cage culture in Molokai, Hawaii. Aquaculture, 219: 379-391.
Neish, A.C., Shacklock, P.F., Fox, C.H. \& Robson, D.R. (1977). The cultivation of Chondrus crispus. Factors affecting growth under greenhouse conditions. Can. J. Bot., 55: 2263-2271.

Nelson, S.G., Glenn, E.P., Conn, J., Moore, D., Walsh, T. \& Akutagawa, M. (2001). Cultivation of Gracilaria parvispora (Rhodophyta) in shrimp-farm effluent channels and floating cages in Hawaii: a two-phase polyculture system. Aquaculture, 193: 239-248.

Neori, A., Cohen, I. \& Gordin, H. (1991). Ulva lactuca Biofilters for Marine Fishpond Effluents II. Growth Rate, Yield and C:N ratio. Bot. Mar., 34: 483-489.

Neori, A., Krom, M.D., Ellner, S.P., Boyd, C.E., Popper, D., Rabinovitch, R., Davidson, P.J., Dvir, O., Zuber, D., Ucko, M., Angel, D. \& Gordin, H. (1996). Seaweed biofilters as regulators of water quality in integrated fish - seaweed culture units. Aquaculture, 141:183-199.

Neori, A., Msuya, F. E., Shauli, L., Schuenhoff, A., Fidi, K. \& Shpigel, M. (2003). A novel threestage seaweed (Ulva lactuca) biofilter design for integrated mariculture. J. Appl. Phycol., 15: 543-553.

Parsons, T., Maita, Y. \& Lalli, C. (1984). A Manual of Chemical and Biological Methods for Seawater Analysis. Pergamon Press, New York, 170 pp.

Qian, P., Wu, C.Y., Wu, M. \& Xie, Y.K. (1996). Integrated cultivation of the red alga Kappaphycus alvarezii and the pearl oyster Pinctada martensi. Aquaculture, 147: 21-35.

Ramus, J. \& Venable, M. (1987). Temporal ammonium patchiness and growth rate in Codium and Ulva (Ulvophyceae). J. Phycol., 23: 518-523.

Shpigel, M., Neori, A., Popper, D.M. \& Gordin, H. (1993). A proposed model for "environmentally clean" land-based culture if fish, bivalves and seaweeds. Aquaculture, 117:155-128.

Subandar, A., Petrell, R.J. \& Harrison, P.J. (1993). Laminaria culture for reduction of dissolved nitrogen in salmon farm affluent. J. Appl. Phycol., 5: $455-463$.

Vandermeulen, H. \& Gordin, H. (1990). Ammonia uptake using Ulva (Chlorophyta) in intensive fishpond system: Mass culture and treatment of effluent. J. Appl. Phycol., 2: 363-374.

Wajisbrot, N., Gasith, A., Krom, M.D. \& Popper, D.M. (1991). Acute toxicity of ammonia to juvenile Gilthead Seabream Sparus aurata under reduced oxygen levels. Aquaculture, 92: 277-288. 